\title{
SIFAT FUNGSIONAL ISOLAT PROTEIN 'BLONDO' (COCONUT PRESSCAKE) DARI PRODUK SAMPING PEMISAHAN VCO (VIRGIN COCONUT OIL) DENGAN BERBAGAI METODE
}

\author{
Functional Properties of Protein Isolates of Blondo (Coconut Presscake) from Side Products of Separation of \\ Virgin Coconut Oil by Various Methods
}

\author{
Siti Permatasari ${ }^{1}$, Pudji Hastuti ${ }^{2}$, Bambang Setiaji ${ }^{3}$, Chusnul Hidayat ${ }^{2}$
}

\begin{abstract}
${ }^{1}$ Fakultas Teknologi Pangan dan Agroindustri, Universitas Mataram, J1. Majapahit 62 Mataram 83125
${ }^{2}$ Fakultas Teknologi Pertanian, Universitas Gadjah Mada, Jl. Flora No.1 Bulaksumur Yogyakarta 55281

${ }^{3}$ Fakultas Matematika dan Ilmu Pengetahuan Alam Universitas Gadjah Mada, Sekip Utara, Bulaksumur, Yogyakarta 55281

Email: sitipermatasari@yahoo.com
\end{abstract}

\begin{abstract}
ABSTRAK
Blondo merupakan hasil samping pengolahan VCO yang memiliki kadar protein cukup tinggi sebesar 24,22\%. Protein blondo belum dimanfaatkan secara maksimal. Protein blondo memiliki sifat fungsional yang dapat mempengaruhi karakteristik produk pangan. Penelitian ini bertujuan untuk menentukan metode pemisahan VCO yang menghasilkan isolat protein dengan sifat fungsional terbaik. Tiga metode pemisahan yang dibandingkan: metode kimia, fisik dan enzimatis. Pada metode kimia dengan pengendapan protein dalam santan pada titik isoelektris dengan menggunakan asam. Pada metode fisik dengan pemecahan sistem emulsi santan dengan penambahan minyak kelapa untuk memperbesar tegangan antar muka protein-air. Metode enzimatis dengan menggunakan protease yang dapat memutus rantai peptida dari protein menjadi molekul yang lebih sederhana. Paramater yang diamati adalah kadar protein, dan sifat fungsional isolat protein blondo VCO yang meliputi Indeks Aktivitas Emulsi (IAE), Indeks Stabilitas Emulsi (ISE), Water Holding Capacity (WHC), Oil Holding Capacity (OHC), Hidrophylic Lipophylic Balance (HLB). Data hasil penelitian dianalisis dengan analisis keragaman dan uji beda nyata jujur pada taraf 5\%. Hasil penelitian menunjukkan bahwa isolat protein blondo VCO yang dibuat dengan metode fisik memberikan kadar protein $(95,12 \pm 2,9 \% \mathrm{db})$, nilai IAE $(37,87 \pm$ $\left.6,6 \mathrm{~m}^{2} / \mathrm{g}\right)$ dan nilai HLB $(42,87 \pm 1,2 \%)$ tertinggi dibandingkan dengan metode kimia dan enzimatis. ISE, WHC dan OHC tidak menunjukkan perbedaan yang signifikan antar metode $(\mathrm{p} \leq 0,05)$. Hasil penelitian ini menyimpulkan bahwa metode fisik menghasilkan sifat fungsional terbaik.
\end{abstract}

Kata kunci: Sifat fungsional, isolat protein, blondo, VCO

\begin{abstract}
Coconut presscake is a byproduct of processing VCO which has a relatively high protein content of $24.22 \%$. Coconut presscake protein not fully utilized. Coconut presscake protein have functional properties that can affect the characteristics of food products. This study aims to determine the separation method of VCO which can produce protein isolate with the best functional properties. Three methods of separation are compared: chemical, physical and enzymatic method. In the chemical method with the precipitation of protein in coconut milk at the isoelectric point using acid. In the physical method by solving coconut milk emulsion system with the addition of coconut oil to increase the interfacial tension of protein-water. Enzymatic method using a protease that can break the chains of peptides of proteins into simpler molecules. Parameters were measured protein content and functional properties of protein isolates of coconut presscake of VCO covering Emulsion Activity Index (EAI), Emulsion Stability Index (ESI), Water Holding Capacity (WHC), Oil Holding Capacity (OHC), Hidrophylic Lipophylic Balance (HLB). Data were analyzed by analysis of variance and Honestly Significant Difference test at 5\% level. The results showed that the protein isolate of coconut presscake of VCO made by physical processed yealded the highest protein content of $95.12 \pm 2.9 \% \mathrm{db}$ and the best functional properties EAI $\left(37.87 \pm 6.6 \mathrm{~m}^{2} / \mathrm{g}\right)$ and HLB $(42.87 \pm 1.2 \%)$ value is highest as compared to chemical and enzymatic processed. ESI,WHC and $\mathrm{OHC}$ showed no significant differences between methods $(\mathrm{p} \leq 0.05)$. The results of this study concluded that the physical method produces the best functional properties.
\end{abstract}

Keywords: Functional properties, protein isolate,coconut presscake, VCO 


\section{PENDAHULUAN}

Blondo (coconut presscake) merupakan hasil samping pembuatan minyak kelapa. Minyak kelapa murni atau dikenal dengan nama Virgin Coconut Oil (VCO) dibuat dengan berbagai cara, diantaranya dengan cara kimia, cara fisik dan cara enzimatis. Prinsip pembuatan VCO dengan cara kimia adalah melalui pengendapan protein dalam santan pada titik isoelektris. $\mathrm{pH}$ santan segar diturunkan dari $\mathrm{pH}$ 6,0 menjadi pH 4,0 menggunakan asam. Pembuatan VCO dengan cara fisik melalui pemecahan sistem emulsi santan dengan menambahkan minyak kelapa untuk memperbesar tegangan antar muka protein-air, sehingga minyak yang terselubung oleh protein dalam sistem emulsi akan keluar dan bergabung dengan minyak yang ditambahkan. Sifat protein blondo yang dihasilkan dengan cara fisik ini tidak berubah (native). Pada cara enzimatis, protease akan memutus rantai peptida dari protein menjadi molekul yang lebih sederhana. Ketiga cara pembuatan VCO ini memberikan pengaruh yang berbeda terhadap protein blondo $\mathrm{VCO}$, sehingga diduga berpengaruh juga terhadap sifat fungsionalnya (Setiaji dan Prayugo, 2006).

Blondo dari VCO yang diperoleh dengan metode fisik mengandung protein (24,22\%), lemak (21,27\%), serat $(0,96 \%)$, dan air $(35,76 \%)$ (Suryawan, 1979 dalam Suzana, 2006). Tingginya kandungan protein pada blondo VCO memungkinkan untuk dimanfaatkan sebagai sumber protein. Beberapa penelitian yang telah dilakukan dengan memanfaatkan protein tepung blondo antara lain sebagai pengganti kacang kedelai dalam pembuatan kecap (Mu'awanah, 2006), sebagai pengemulsi dalam pembuatan sosis (Meirinna, 2006) dan sebagai pengganti sebagian tepung terigu dalam pembuatan biskuit (Suzana, 2006). Menurut Mepba dkk. (2008), konsentrat protein kelapa memiliki kemampuan pembentukan emulsi yang baik,namun kemampuan pembentukan buih yang rendah. Onsaard dkk. (2006) menyatakan bahwa krim protein kelapa dengan metode freez thaw lebih efektif sebagai emulsifier daripada metode pengasaman, berdasarkan ukuran partikel dan index creaming. Menurut Naik, dkk. (2012), aktivitas emulsi pada tepung protein kelapa dari limbah pengolahan VCO secara enzimatis menggunakan enzim protease adalah $40 \mathrm{~m}^{2} / \mathrm{g}$, tertinggi dibandingkan dengan tepung kedele rendah lemak $\left(17,36 \mathrm{~m}^{2} / \mathrm{g}\right)$ dan tepung susu skim $\left(33,0 \mathrm{~m}^{2} / \mathrm{g}\right)$. Meskipun telah banyak yang mempelajari tentang protein dan sifat fungsional protein kelapa, namun sejauh ini belum ada penelitian tentang sifat fungsional protein dari isolat protein blondo yang dibuat dari berbagai cara pembuatan VCO. Kandungan protein yang tinggi pada blondo juga dapat dimanfaatkan dalam bentuk isolat protein. Isolat protein minimal mengandung protein sebesar $85 \% \mathrm{db}$. Sifat fungsional protein blondo yang dapat diaplikasikan pada pangan antara lain indeks aktivitas dan stabilitas emulsi, kemampuan menyerap air dan kemampuan menyerap minyak dan sebagainya. Sifat fungsional protein akan menentukan karakteristik produk pangan. Penelitian ini bertujuan untuk menentukan metode pemisahan VCO yang menghasilkan isolat protein dengan sifat fungsional terbaik

\section{METODE PENELITIAN}

\section{Rancangan Percobaan}

Percobaan dirancang dengan rancangan acak lengkap dengan perlakuan metode pembuatan VCO yaitu secara kimia, fisik dan enzimatis. Masing-masing perlakuan dibuat tiga kali ulangan. Data yang diperoleh dianalisis dengan analisis keragaman pada taraf nyata $5 \%$ dan uji lanjut dengan uji beda nyata jujur pada taraf nyata $5 \%$.

\section{Bahan dan Alat}

Bahan yang digunakan: daging buah kelapa dalam dengan tingkat ketuaan 10-11 bulan ditandai dengan kulit dan serabut berwarna coklat tua yang diperoleh dari petani kelapa di Kecamatan Tanjung Kabupaten Lombok Utara. Bahan kimia meliputi air distilat, heksan teknis, asam asetat, minyak VCO diperoleh dari Laboratorium Kimia dan Teknologi Pangan Fatepa Unram. Bahan kimia $\mathrm{NaOH}$ dan $\mathrm{HCl}$ diperoleh dari Merck, enzim papain kasar (getah pepaya) diperoleh dari kebun petani, minyak jagung merk Tropicana Slim diperoleh dari Supermarket Gading Mas Yogya dan bahan kimia lain untuk analisis sifat kimia dan sifat fungsional protein diperoleh dari Laboratorium Kimia dan Teknologi Pangan FTP UGM.

Alat yang digunakan: mesin pemarut kelapa, toples plastik, mixer merk Kirin, gelas ukur, kain saring, toples plastik, nampan plastik, corong, Digital orbital and shaker (Heidolph Germany Unimax 1010), timbangan analitik (Kern Germany ABJ 220-4M), Top Loading Balance (Kern Germany EW600-2M)), pH meter (Schoot-Germany Handylab $\mathrm{pH}$ 11), Multipurposes Centrifuges (Hettich-Germany Universal 320), Combine Refrigerator (Fiocchetti-Italy Vision 2T 400), Shieve Shaker (Retsch-Germany As 200 digit), Universal Mill (IKA-Germany M20), Universal Oven (Memmert-Germany UFB 500), Freeze Dryer (Martin Christ-Germany Alpha 1,2 LD Plus).

\section{Pembuatan Virgin Coconut Oil (VCO)}

Pembuatan VCO diawali dengan proses ekstraksi santan dengan cara sebagai berikut: kelapa dikupas dan diambil dagingnya kemudian diparut. Kelapa parut kemudian diekstrak dengan menambahkan air dengan perbandingan $1: 1$, lalu diperas santannya. Santan didiamkan selama kurang lebih dua jam sehingga terpisah menjadi dua lapisan yaitu 
lapisan bawah (skim) dan lapisan atas (krim). Lapisan krim diambil sebagai bahan baku pembuatan VCO.

Pembuatan VCO cara kimia: lapisan krim diatur keasamannya hingga $\mathrm{pH}$ 4,0 menggunakan asam asetat $25 \%$, campuran diaduk selama 2 menit hingga homogen. Setelah itu diinkubasi selama 12 jam pada suhu kamar sehingga terbentuk tiga lapisan dari atas ke bawah terdiri atas minyak, blondo dan air (Setiaji dan Prayugo, 2006).

Pembuatan VCO cara fisik lapisan krim ditambah minyak VCO dengan perbandingan 3:1. Campuran diaduk selama 2 menit sampai homogeny. Setelah itu diinkubasi selama 12 jam pada suhu kamar, sehingga terbentuk tiga lapisan dari atas ke bawah terdiri atas minyak, blondo dan air (Setiaji dan Prayugo, 2006).

Pembuatan VCO cara enzimatis: lapisan krim ditambahkan enzim papain kasar (getah pepaya) pada konsentrasi 0,06\%. Campuran diaduk selama 2 menit sampai homogeny. Setelah itu diinkubasi selama 12 jam pada suhu kamar sehingga terbentuk tiga lapisan dari atas ke bawah terdiri atas minyak, blondo dan air (Winarti dkk., 2007).

\section{Pembuatan Tepung Blondo Rendah Minyak}

Blondo disentrifugasi dilakukan dengan kecepatan $1610 \mathrm{xg}$ selama 3x6 menit. Selanjutnya blondo yang sudah berbentuk pasta kental diekstraksi menggunakan heksan dengan perbandingan 1:2, ditempatkan pada shaker dengan kecepatan $250 \mathrm{rpm}$, selama 2x120 menit pada suhu ruang. Blondo rendah minyak selanjutnya dikeringanginkan selama 5 menit, kemudian diblender selama 3 menit dan diayak menggunakan ayakan 40 mesh.

\section{Pembuatan Isolat Protein Blondo VCO}

Pembuatan isolat protein blondo VCO mengacu pada metode pembuatan isolat protein kedele (Sorgentini dan Wagner, 2001; Molina dkk., 2001) yang dimodifikasi: tepung blondo VCO rendah minyak sebanyak $1 \mathrm{~g}$ dalam $20 \mathrm{ml}$ air destilat diekstraksi selama 60 menit pada suhu ruang. $\mathrm{pH}$ diatur pada $\mathrm{pH} 11$ dengan menggunakan $2 \mathrm{~N} \mathrm{NaOH}$. Campuran selanjutnya disentrifugasi pada $2862 \mathrm{xg}$ selama 15 menit pada suhu $20^{\circ} \mathrm{C}$. Supernatan diambil dan protein diendapkan pH 4 dengan $2 \mathrm{~N} \mathrm{HCl}$. Campuran diinkubasi selama 2 jam pada suhu $4^{\circ} \mathrm{C}$, kemudian disentrifugasi kembali pada 2862 g selama 20 menit pada suhu $20^{\circ} \mathrm{C}$. Endapan yang diperoleh selanjutnya dicuci dengan air, kemudian dikeringbekukan (freeze-dried) selama $20 \mathrm{jam}$. Tepung isolat protein blondo VCO disimpan pada lemari pendingin suhu $-20^{\circ} \mathrm{C}$.

\section{Penentuan Kelarutan Protein}

Sebanyak $1 \mathrm{~g}$ blondo rendah minyak disuspensikan dalam $20 \mathrm{ml}$ air destilat, kemudian diatur pH 2 hingga12 dengan menambahkan $2 \mathrm{~N} \mathrm{NaOH}$ atau $2 \mathrm{~N} \mathrm{HCl}$. Larutan kemudian dihomogenisasi menggunakan waterbath shaker pada suhu $30^{\circ} \mathrm{C}$ selama 60 menit. Supernatan yang mengandung protein terlarut dipisahkan dengan sentrifugasi pada 4000 xg selama 30 menit. Kadar protein terlarut pada supernatan diuji menurut metode Lowry-Folin (Lowry dkk., 1951).

\section{Penentuan Water Holding Capacity (WHC) dan Oil Holding Capacity (OHC)}

Water Holding Capacity (WHC) ditentukan menurut metode Sze dkk. (2000) yang sedikit dimodifikasi. Sebanyak $1 \mathrm{~g}$ isolat protein blondo disuspensikan dalam $10 \mathrm{ml}$ air destilat, dibiarkan selama 60 menit, diaduk dengan pengaduk magnetik kemudian disentrifugasi selama 30 menit pada 28,6 xg. Supernatan didekantasi dan residu yang diperoleh ditimbang. WHC dinyatakan sebagai jumlah gram air yang diserap per gram isolat protein blondo.

Oil Holding Capacity (OHC) ditentukan dengan cara yang sama dengan penentuan WHC, namun air destilat diganti dengan minyak jagung merk Tropicana Slim. OHC dinyatakan sebagai jumlah gram minyak yang diserap per gram isolat protein blondo.

\section{Penentuan IAE (Indeks Aktivitas Emulsi) dan ISE (Indeks Stabilitas Emulsi)}

Pengujian sifat emulsi dari isolat protein blondo dilakukan menurut metode Pearce dan Kinsella (1978) dalam Naik dkk. (2012). Sebanyak $2 \mathrm{ml}$ minyak jagung jernih ditambah $6 \mathrm{ml}$ larutan protein $0,1 \%(0,1 \mathrm{M} \mathrm{pH} \mathrm{7,0}$ buffer fosfat) lalu dihomogenisasi selama 2 menit pada suhu ruang. Sebanyak $50 \mu \mathrm{l}$ emulsi dipipetkan dari dasar wadah pada 0 menit dan 10 menit, masing-masing ditambah 0,1\% larutan SDS $5 \mathrm{ml}$. Absorbansi diukur pada $\lambda 500 \mathrm{~nm}$.

$$
\begin{aligned}
\text { IAE } & \left(\mathrm{m}^{2} / \mathrm{g}\right)=\frac{2 T\left[\left(A_{0} \times F P\right)\right]}{(1-v) \times C \times 1000} \\
\mathrm{~T}= & 2,303 \\
\mathrm{~A}_{0}= & \text { Absorbansi pada menit ke } 0 \text { setelah terbentuk } \\
& \text { emulsi } \\
\mathrm{FP}= & \text { Faktor pengenceran } 100 \\
\mathrm{~V}= & \text { fraksi volume minyak jagung dari emulsi } \\
\mathrm{C}= & \text { konsentrasi protein }(\mathrm{g} / \mathrm{ml})
\end{aligned}
$$

$$
I S E=\left\lfloor\frac{A_{o} x \Delta}{\Delta_{A}} t\right\rfloor
$$

$\Delta_{t}=10$ menit

$\Delta_{\mathrm{A}}=\mathrm{A}_{\mathrm{o}}-\mathrm{A}_{10}$ 
Penentuan Hydrophylic-Lypophylic Balance (HLB) (Macedo dkk.2006)

Pembuatan standar nilai HLB menggunakan Tween 80 dan Span 80 seperti pada Tabel 1.

Tabel 1. Nilai HLB pada berbagai rasio Tween dan Span

\begin{tabular}{|c|c|c|c|c|c|}
\hline \multicolumn{2}{|c|}{ Tween 80} & \multicolumn{2}{|c|}{ Span 80} & \multirow{2}{*}{$\begin{array}{l}\text { Nilai } \\
\text { HLB }\end{array}$} & \multirow{2}{*}{$\begin{array}{c}\text { HLB } \\
(\%)\end{array}$} \\
\hline$\%$ & $\mathrm{ml}$ & $\%$ & $\mathrm{ml}$ & & \\
\hline 100 & 0,40 & 0 & 0 & 15,00 & 41,693 \\
\hline 80 & 0,32 & 20 & 0,08 & 12,86 & 38,961 \\
\hline 60 & 0,24 & 40 & 0,16 & 10,72 & 36,910 \\
\hline 40 & 0,16 & 60 & 0,24 & 8,58 & 35,590 \\
\hline 20 & 0.08 & 80 & 0,32 & 6,44 & 34,213 \\
\hline 0 & 0 & 100 & 0,40 & 4,30 & 32,075 \\
\hline
\end{tabular}

Masing-masing kombinasi pada Tabel 1 ditambah dengan $10 \mathrm{ml}$ air destilat dan $5 \mathrm{ml}$ minyak jagung kemudian dihomogenisasi pada $2000 \mathrm{rpm}$ selama 30 detik, kemudian ditambahkan $5 \mathrm{ml}$ minyak jagung dan dihomogenisasi selama 90 detik. Nilai HLB dinyatakan dalam persen volume emulsi yang terbentuk dibandingkan dengan volume awal campuran.

Penentuan nilai HLB dari sampel dilakukan dengan menambahkan $10 \mathrm{ml}$ larutan protein dengan konsentrasi 0,5\% dengan $5 \mathrm{ml}$ minyak jagung. Selanjutnya dihomogenisasi selama 30 detik pada kecepatan 17888 g 10000 rpm. Kemudian ditambahkan lagi $5 \mathrm{ml}$ minyak jagung dan dihoomogenisasi lagi selama 90 detik. Selanjutnya campuran disentrifugasi dengan kecepatan $3000 \mathrm{xg}$ selama 5 menit. Volume non emulsi yang terbentuk diukur. Penghitungan nilai HLB menurut persamaan:

Nilai $H L B=\frac{\text { volume fase non emulsi } / \mathrm{ml} \times 100 \%}{\text { Volume total }(\mathrm{ml})}$ Volume total (ml)

\section{HASIL DAN PEMBAHASAN}

\section{Isolat Protein Blondo VCO}

Prinsip proses isolasi protein blondo VCO adalah pelarutan dilakukan pada $\mathrm{pH}$ tertinggi dan pengendapan pada $\mathrm{pH}$ terendah berdasarkan profil kelarutan protein pada berbagai $\mathrm{pH}$.

Profil kelarutan protein dari tepung blondo rendah minyak disajikan pada Gambar 1. Profil kelarutan protein dari tepung blondo rendah minyak yang diperoleh dari tiga cara pembuatan VCO memberikan pola yang sama. Pada $\mathrm{pH}$ rendah sebagian besar gugus karboksil dan gugus amino dari rantai samping asam amino berturut-turut diprotonasi menjadi bentuk ${ }^{-} \mathrm{COOH}$ dan $\mathrm{NH}_{3}^{+}$dan muatan keseluruhan dari sebagian besar protein adalah positif. (Adebowale dan

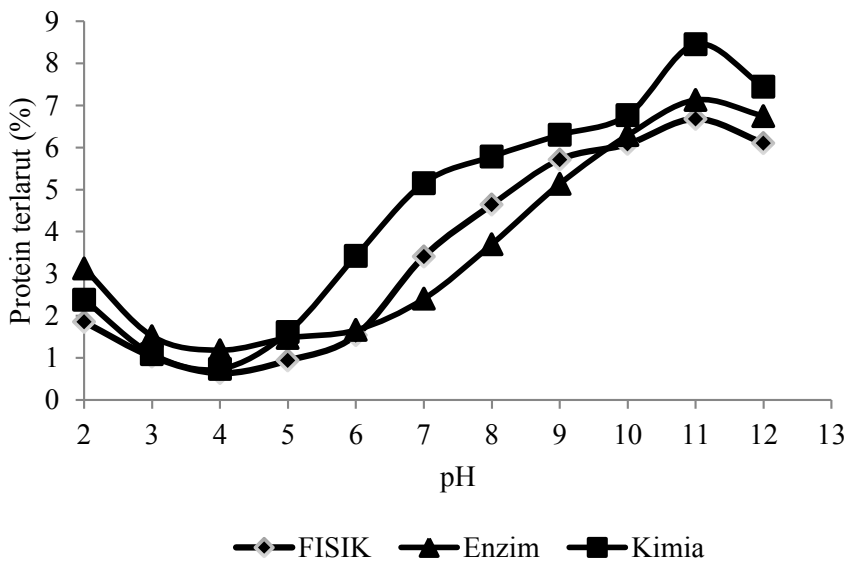

Gambar 1. Profil kelarutan protein tepung blondo rendah minyak pada berbagai $\mathrm{pH}$

Adebowale, 2008). Penurunan kelarutan protein dari $\mathrm{pH} 2,0$ hingga titik terendah (titik isoelektris) pada $\mathrm{pH} \mathrm{4}$, karena terdisosiasi gugus $\mathrm{COOH}$ dan $\mathrm{NH}_{2}$ dari asam amino menjadi $\mathrm{COO}^{-}$dan $\mathrm{NH}_{3}^{+}$. Hal ini menyebabkan kemampuan mengikat air menurun sehingga kelarutan menurun dan protein mengendap. Menurut Fennema (1976) dan Kusnandar (2011) muatan total masing-masing asam amino pada titik isoelektrik protein adalah sama dengan nol, artinya terjadi keseimbangan antara gugus bermuatan positif dan gugus bermuatan negatif sehingga protein mengendap. Hasil yang dilaporkan oleh Kwon dan Samson titik isoelektrik konsentrat protein kelapa berada pada kisaran pH 4-5 (Chambal dkk., 2013). Kelarutan protein meningkat sampai dengan $\mathrm{pH} 11$. Hal ini terjadi karena gugus amina tereduksi menghasilkan $\mathrm{NH}_{2}$, sedangkan gugus karboksil terdisosiasi menjadi $\mathrm{COO}^{-}$dan $\mathrm{H}^{+}$sehingga protein menjadi bermuatan negatif. Kelarutan protein yang tinggi pada $\mathrm{pH}$ basa menyebabkan ekstraksi protein umumnya dilakukan pada pH 10-12 (Lorenzo, 2008). Kelarutan protein berkurang pada di atas $\mathrm{pH} 11$ kemungkinan terjadi karena denaturasi protein. Menurut Kusnandar (2011) bahwa pada $\mathrm{pH}$ di bawah titik isoelektris protein cenderung bermuatan positif. Sebaliknya pada $\mathrm{pH}$ di atas titik isoelektris protein cenderung bermuatan negatif. Semakin jauh $\mathrm{pH}$ dari titik isoelektrisnya, maka kelarutan protein meningkat. Kelarutan protein pada $\mathrm{pH}$ basa lebih tinggi dibandingkan $\mathrm{pH}$ asam karena jumlah muatan negatif residu asam amino pada rentang $\mathrm{pH}$ basa lebih banyak daripada jumlah muatan positif pada rentang $\mathrm{pH}$ asam.

Kadar protein dan ekstrak protein kembali isolat protein blondo dari VCO yang dibuat dari tiga cara yang berbeda disajikan pada Tabel 2 . 
Tabel 2. Kadar protein dan ekstrak protein kembali isolat protein blondo dari $\mathrm{VCO}$

\begin{tabular}{lcc}
\hline \multirow{2}{*}{$\begin{array}{c}\text { Metode pembuatan } \\
\text { VCO }\end{array}$} & \multicolumn{2}{c}{ Isolat protein blondo VCO } \\
\cline { 2 - 3 } & $\begin{array}{c}\text { Kadar protein } \\
(\% \mathrm{db})\end{array}$ & $\begin{array}{c}\text { Ekstrak protein } \\
\text { kembali }(\% \mathrm{db})\end{array}$ \\
\hline Kimia & $86,26 \pm 2,6 \mathrm{a}$ & $37,89 \pm 1,9 \mathrm{a}$ \\
Fisik & $95,12 \pm 2,9 \mathrm{~b}$ & $48,18 \pm 11,7 \mathrm{a}$ \\
Enzimatis & $90,71 \pm 2,5 \mathrm{ab}$ & $45,05 \pm 1,6 \mathrm{a}$ \\
\hline BNJ 0,05 & 6,78 & - \\
\hline Keterangan: & angka yang diikuti dengan huruf yang sama & menunjukkan \\
& tidak berbeda nyata
\end{tabular}

Kadar protein pada isolat protein blondo dari VCO yang dibuat dengan tiga cara menunjukkan perbedaan nyata dengan nilai BNJ 0,05\% adalah 6,78. Kadar protein terendah pada isolat protein blondo dari $\mathrm{VCO}$ yang dibuat dengan cara kimia sebesar 86,26 $\pm 2,6 \% \mathrm{db}$ dengan ekstrak protein kembali sebesar $37,89 \pm 1,9 \%$, kemudian diikuti dengan isolat protein blondo dari VCO yang dibuat dengan cara enzimatis sebesar $90,71 \pm 2,5 \% \mathrm{db}$ dengan ekstrak protein kembali sebesar 45,05 $\pm 1,6 \%$. Kadar protein tertinggi pada isolat protein blondo dari $\mathrm{VCO}$ yang dibuat dengan cara fisik sebesar 95,12 $\pm 2,9$ dengan ekstrak protein kembali sebesar $48,18 \pm 11,7 \%$. Isolat protein blondo dari VCO yang dibuat dengan cara fisik dan enzimatis memiliki kadar protein lebih tinggi dari hyacinth beans (kacang koro komak) sebesar $89,8 \pm 0,82 \% d b$ (Subagio, 2006). Ekstrak protein kembali dalam pembuatan isolat protein tidak dapat mencapai $100 \%$. Menurut Chavan dkk. (2001) bahwa protein yang membentuk kompleks dengan senyawa lain seperti karbohidrat dan lemak sehingga sulit untuk diekstrak kebali. Subagio (2006) menyatakan hanya sekitar $50 \%$ protein yang diekstrak dapat diendapkan pada $\mathrm{pH} 4,0$ - 4,5. Isolat protein blondo dari VCO yang diendapkan pd pH 4 memiliki ekstrak protein kembali yang lebih rendah dari biji jarak sebesar 51,4\% (Prastowo, 2009), tetapi lebih tinggi dari biji kapas sebesar $24,7 \%$ (Tsaliki dkk., 2003). Perbedaan persentase ekstrak protein kembali disebabkan oleh perbedaan komposisi kimia protein. Perbedaan konformasi protein dan perbedaan sisi pengikatan yang terdapat pada protein dapat mempengaruhi kelarutan protein dan pengendapan pada titik isoelektris selama pembuatan isolat protein (Sanjeewa, 2008).

\section{Water Holding Capacity (WHC) dan Oil Holding Capacity (OHC)}

Nilai WHC dan OHC isolat protein blondo dari VCO yang dibuat dengan tiga cara berbeda disajikan pada Tabel 3 .
Tabel 3. Nilai WHC dan OHC isolat protein blondo dari VCO

Isolat protein blondo $\mathrm{VCO}$

\begin{tabular}{lcc}
$\begin{array}{c}\text { Metode pembuatan } \\
\text { VCO }\end{array}$ & $\begin{array}{r}\text { WHC (g air/g } \\
\text { isolat protein) }\end{array}$ & $\begin{array}{c}\text { OHC (ml } \\
\text { minyak/g isolat } \\
\text { protein) }\end{array}$ \\
\cline { 2 - 3 } Kimia & $3,41 \pm 1,0 \mathrm{a}$ & $0,81 \pm 0,1 \mathrm{a}$ \\
Fisik & $2,45 \pm 0,2 \mathrm{a}$ & $0,95 \pm 0,1 \mathrm{a}$ \\
Enzimatis & $2,87 \pm 0,5 \mathrm{a}$ & $0,92 \pm 0,4 \mathrm{a}$ \\
\hline BNJ 0,05 & - & - \\
\hline Keterangan: & angka yang diikuti dengan huruf yang sama & menunjukkan \\
& tidak berbeda nyata
\end{tabular}

Interaksi antara protein dengan air atau protein dengan minyak sangat penting dalam sistem pangan karena berpengaruh terhadap flavour dan tekstur pangan (Kanu dkk., 2007 dalam Essuman dkk., 2014). Penyerapan air tergantung pada beberapa parameter seperti ukuran, konfigurasi, konformasi, keseimbangan hidrofobik dan hidrofilik protein (Chavan dkk., 2001 dalam Essuman dkk., 2014).

Nilai Water Holding Capacity (WHC) Isolat Protein Blondo dari VCO yang dibuat dengan cara kimia, fisik dan enzimatis tidak menunjukkan perbedaan nyata. Nilai WHC isolat protein blondo berkisar antara 2,45-3,41 $\mathrm{g}$ air/g, hampir sama dengan isolat protein kecipir sebesar 2,61 g air/g (Budijanto dkk., 2011), tetapi lebih tinggi dari isolat protein wijen sebesar 2,10 g air/g (Khalid dkk., 2003) dan konsentrat protein kedele yaitu 2,20 g air/g (Kinsella,1979). Menurut Hudson (1994) WHC konsentrat protein kedele berkisar antara 2,40 - 3,40 g air/g.

Nilai Oil Holding Capacity (OHC) Isolat Protein Blondo dari VCO yang dibuat dengan cara kimia, fisik dan enzimatis tidak menunjukkan perbedaan nyata dengan kisaran nilai $0,81-0,95 \mathrm{ml} / \mathrm{g}$. Nilai OAC isolat protein blondo VCO lebih rendah jika dibandingkan dengan isolat protein lainnya seperti pada: ginkgo biloba 2,95 $\mathrm{ml} / \mathrm{g}$ dan chicpea $1,7 \mathrm{ml} / \mathrm{g}$ (Lopez dkk., 1991), wijen 1,5 ml/g (Khalida dkk., 2003), kecipir 1,60 ml /g (Budijanto dkk., 2011) dan kedele 1,33$1,54 \mathrm{ml} / \mathrm{g}$ (Kinsella, 1979). Pengikatan minyak pada produk bubuk dipengaruhi oleh ukuran partikel. Protein dalam bentuk bubuk dengan ukuran partikel kecil serta dengan densitas yang rendah mengadsorbsi dan memerangkap minyak lebih banyak dibandingkan protein yang densitasnya tinggi (Zayas, 1997). Perbedaan OAC kemungkinan karena perbedaan sifat pembentukan, hidrofobisitas permukaan, grup lipofilik dan degenerasi protein (Deng dkk., 2011). 
Indeks Aktivitas Emulsi (IAE) dan Indeks Stabilitas Emulsi (ISE)

Nilai IAE dan ISE isolat protein blondo dari VCO disajikan pada Tabel 4.

Tabel 4. Nilai IAE, ISE dan HLB isolat protein blondo dari $\mathrm{VCO}$

\begin{tabular}{lccc}
\hline \multicolumn{1}{c}{ Metode } & \multicolumn{3}{c}{ Isolat protein blondo } \\
pembuatan VCO & IAE $\left(\mathrm{m}^{2} / \mathrm{g}\right)$ & ISE (menit) & HLB $(\%)$ \\
\hline Kimia & $17,45 \pm 4,8 \mathrm{a}$ & $13,04 \pm 2,4 \mathrm{a}$ & $36,10 \pm 0,4 \mathrm{~b}$ \\
Fisik & $37,87 \pm 6,6 \mathrm{~b}$ & $11,26 \pm 0,3 \mathrm{a}$ & $42,87 \pm 1,2 \mathrm{a}$ \\
Enzimatis & $30,30 \pm 4,2 \mathrm{ab}$ & $10,62 \pm 0,4 \mathrm{a}$ & $37,44 \pm 0,9 \mathrm{~b}$ \\
\hline BNJ 0,05 & 13,27 & - & 2,23 \\
\hline
\end{tabular}

Keterangan : angka yang diikuti dengan huruf yang sama menunjukkan tidak berbeda nyata

Indeks Aktivitas Emulsi (IAE) mencerminkan kemampuan produk isolat dalam berinteraksi dengan air dan minyak selama pembentukan emulsi. Nilai IAE isolat protein blondo dari tiga cara pembuatan VCO berbeda nyata. Nilai IAE terendah pada isolat protein blondo dari VCO yang dibuat dengan cara kimia sebesar 17,45 $\pm 4,8 \mathrm{~m}^{2} / \mathrm{g}$ kemudian diikuti dengan isolat protein blondo dari VCO yang dibuat dengan cara enzimatis sebesar $30,30 \pm 4,2 \mathrm{~m}^{2} / \mathrm{g}$. Nilai IAE tertinggi pada isolat protein blondo dari VCO yang dibuat dengan cara fisik sebesar 37,87 $\pm 6,6 \mathrm{~m}^{2} / \mathrm{g}$. Perbedaan nilai IAE disebabkan oleh bahan baku dari isolat protein yaitu blondo memiliki kadar protein yang berbeda karena perbedaan cara pembuatan VCO. IAE pada isolat protein blondo dari VCO yang dibuat secara fisik diperoleh nilai tertinggi diduga cara fisik tidak merusak protein blondo dan isolatnya. Hal ini berdasarkan hasil pengamatan kadar protein blondo VCO yang dibuat secara fisik tertinggi yaitu 77,65 $\% \mathrm{db}$, kemudian cara kimia sebesar 72,194 \%db dan terendah pada cara enzimatis sebesar $63,55 \% \mathrm{db}$. Nilai IAE pada isolat protein blondo VCO yang dibuat dengan cara fisik hampir mendekati tepung protein kelapa $\left(40 \mathrm{~m}^{2} / \mathrm{g}\right)$ tetapi lebih tinggi dibandingkan dengan tepung kedele rendah lemak (17,36 $\mathrm{m}^{2} / \mathrm{g}$ ) dan susu skim $\left(33,0 \mathrm{~m}^{2} / \mathrm{g}\right)$ (Naik dkk., 2012).

Indeks Stabilitas Emulsi (ISE) merupakan tolok ukur kemampuan produk isolat dalam mempertahankan kestabilan emulsi. Nilai ISE isolat protein blondo dari tiga cara pembuatan VCO tidak menunjukkan perberbedaan nyata dengan kisaran nilai 10,62-13,0 menit. Subagio (2006) melaporkan nilai ISE kacang komak sebesar 2,7 $\pm 0,1$ jam, sangat rendah dibandingkan isolat protein kedele sebesar 52,0 $\pm 3,8$ jam.

\section{Hidrophylic Lipophylic Balance (HLB)}

Nilai HLB isolat protein blondo dari VCO yang dibuat secara kimia, fisik dan enzimtis disajikan pada Tabel 4 menunjukkan perbedaan nyata dengan nilai BNJ $0,05 \%$ adalah 2,23. Nilai HLB terendah dihasilkan oleh isolat protein blondo dari VCO yang dibuat dengan cara kimia sebesar 36,10 \pm $0,4 \%$ dan cara enzimatis sebesar $37,44 \pm 0,9 \%$ yang setara dengan nilai HLB standar yang digunakan sebesar 10,72. Nilai HLB tertinggi dihasilkan oleh isolat protein blondo VCO yang dibuat dengan cara fisik sebesar $42,87 \pm 1,2 \%$ yang setara dengan nilai HLB standar 15. Dengan demikian, isolat protein blondo dari VCO yang dibuat secara kimia, fisik dan enzimatis memiliki nilai HLB tinggi artinya lebih bersifat hidrofilik dan lebih terlarut pada fase air sehingga dapat digunakan sebagai emulsifier. Menurut Dickinson dan McClements (1996) dan McClements (1999), emulsifier dengan nilai HLB rendah (3-6) bersifat hidrofobik dan lebih terlarut pada fase minyak sehingga akan membentuk emulsi water in oil (W/O), sedangkan emulsifier dengan nilai HLB tinggi (8-18) lebih bersifat hidrofilik dan lebih terlarut pada fase air, sehingga akan menstabilkan emulsi oil in water $(\mathrm{O} / \mathrm{W})$.

\section{KESIMPULAN}

Profil kelarutan protein tepung blondo rendah minyak yang dibuat secara kimia, fisik dan enzimatis memiliki pola yang sama. Kelarutan tertinggi diperoleh pada $\mathrm{pH} 11$ dan terendah pada $\mathrm{pH}$ 4. Isolat protein blondo dari VCO yang dibuat dengan cara fisik memberikan kadar protein tertinggi sebesar 95,12 $\pm 2,9 \% \mathrm{db}$ dengan perolehan protein kembali sebesar $48,18 \pm 11,7 \%$ dan sifat fungsional terbaik dengan nilai IAE dan HLB tertinggi. Nilai ISE, WHC dan OHC tidak menunjukkan perbedaan yang nyata antar metode. Isolat protein blondo dari VCO yang dibuat dengan metode fisik memiliki sifat sebagai emulsifier terbaik. Isolat protein blondo VCO yang dibuat dengan metode fisik dengan nilai IAE dan HLB tertinggi memiliki sifat sebagai emulsifier terbaik sehingga sangat cocok diaplikasikan dalam pembuatan es krim, cake dan biskuit.

\section{DAFTAR PUSTAKA}

Aluko, R.E. dan Yada, R.Y. (1993). Relationship of hydrophobicity and solubility with some functional properties of cowpea (Vigna unguculata) protein isolate. Journal of the Science of Food and Agriculture 37: 553-559.

Budijanto, S., Sitanggang, A.B. dan Murdiati, W. (2011). Karakterisasi sifat fisiko-kimia dan fungsional isolat 
protein biji kecipir (Psophocarpus tetragonolobus L). Jurnal Teknologi dan Industri Pangan XXII(2): 130136.

Chambal, B., Bergenstahl, B. dan Dejmek, P. (2012). Edible protein from coconut milk press cake: one step alkaline extraction and characteristization by electrophoresis and mass spectrometry. Food Research International 47(2): 146-151.

Chavan, U.D., McKenzie, D.B. dan Shahidi, F. (2001). Protein classification of beach pea. Dalam: Influence of $\mathrm{pH}$ on the extraction yield and functional properties of Macadamia (Macadamia integrofolia) protein isolates. Food Science and Technology International 10: 263267.

Dickinson, E. dan McClements, D.J. (1996). Advances in Food Colloids. Blackie Academic and Professional, London.

Deng, Q., Wang, L., Wei, F., Xie, B., Huang, F., Huang, W., Shi, J., Huang, Q., Tian, B. dan Xue, S. (2011). Functional properties of protein isolates, globulin and albumin extracted from Ginkgo biloba seeds. Food Chemistry 124: 1458-1465.

Essuman, E.K., Ankar-Brewoo, G.M., Barimah, J. dan Ofosu, I.W. (2014). Functional properties of protein isolat from fern fronds. International Food Research Journal 21(5): 2085-2090.

Fennema, J.R. (1976). Food Chemistry. Marceldekker Incorporation, New York.

Hudson, B.J.F. (1994). New and Developing Sources of Food Proteins. Chapman and Hall, London.

Khalid, E.K., Babiker, E.E. dan Tinay, A.H.E.L. (2003). Solubility and functional properties of sesame seed proteins as influenced by $\mathrm{pH}$ and/or salt concentration. Food Chemistry 82(2003): 361-366.

Kinsella, J.E. (1979). Functional properties of soy proteins. Journal of the American Oil Chemists' Society 56: 242246.

Kusnandar, F. (2011). Kimia Pangan. Komponen Makro. Cetakan 1. Dian Rakyat, Jakarta.

Lopez, Q.P., Falomir, C.O. dan Olivares, V.M.R. (1991). Chickpea protein Isolates: Physicochemical, functional and nutritional characterization. Journal of Food Science 56: 726-729.

Lorenzo, L.K. (2008). Improving the Solubility of Yellow Mustard Precipitated Protein Isolate in Acidic Aqueous Solutions. Tesis. University of Toronto, Toronto.
Lowry, O.H., Rosebrough, N.J., Farr, A.L. dan Randall, R.J. (1951). Protein measurement with the folin phenol reagent. The Journal of Biological Chemistry 193: 265275 .

Macedo, J.P.F., Leonardo, L., Fernandes, F.R., Formiga, M.F., Reis, T.N., Junior, L.A., Soares, L. dan Socrates, T.E. (2006). Micro-emultocrit technique. The valuable tool for determination of critical HLB value of emultions. American Association of Pharmaceutical Scientists. Pharmaceutical Science Technology 7: 21.

McClements, D.J. (1999). Food Emulsions, Principlels, Practice, and Techniques. Chemical Rubber Company Pess. New York.

Meirinna (2006). Pemanfaatan Blondo Minyak Kelapa sebagai Kelapa sebagai Pengemulsi Dalam Pembuatan Sosis. Skripsi. Jurusan Kimia. Fakultas Matematika dan Ilmu Pengetahuan Alam. Universitas Gadjah Mada, Yogyakarta.

Mepba, H.D., Achinewhu, S.C. dan Ademiluyi, T. (2008). Solubility, emulsion and foaming poroperties of coconut (Cocos nucifera) protein concentrates. African Journal of Food Agriculture, Nutrition and Development Online 8(2): 170-191.

Molina, E., Papadopoulou, A. dan Ledward, D.A. (2001). Emulsiying properties of high pressure treated soy protein isolate and $7 \mathrm{~S}$ and $11 \mathrm{~S}$ globulins. Food Hydrocolloids 15: 263-269.

Mu'awanah, I.A.U. (2006). Pengaruh Larutan Garam dan Jumlah Blondo Terhadap Sifat Fisika Kimia Kecap Blondo. Skripsi. Jurusan Kimia. Fakultas Matematika dan Ilmu Pengetahuan Alam. Universitas Gadjah Mada, Yogyakrta.

Naik, A., Raghavendra, S.N. dan Raghavarao, K.S.M.S. (2012). Production of coconut protein powder from coconut wet processing waste and its characterization. Applied Biochemistry and Biotechnology 167(5): 1290302.

Onsaard, E., Vittayanont, M., Srigam, S. dan McClements, D.J. (2006). Comparison of properties oil-in-water emulsions stabilized by coconut cream proteins with those stabilizaed by whey protein isolate. Food Research International 39: 78-86.

Prastowo, Y.B. (2009). Isolasi dan karakterisasi sifat fungsional dari bungkil biji jarak pagar (Jatropa curcas L). Skripsi. Fakultas Teknologi Pertanian. Universitas Gadjah Mada, Yogyakarta. 
Salil, G., Nevin, K.G. dan Rajamohan, T. (2011). Arginine rich coconut kernel protein modulates diabetes in alloxan treated rats. Chemico-Biological Interactions 189(2011): 107-111.

Sanjeewa, W.G.T. (2008). Physico-chemical properties of chickpea flour, starch and proteinf fractions and their utilization in low-fat pork bologna. Tesis. Departement of Food and Bioproduct Sciences. University of Saskatchewan, Canada.

Sathe, S.K., Deshpande, S.S. dan Salunkhe, D.K. (1982). Functional properties of lupin seed (Lupinus mutabilis) proteins and protein concentrates. Journal of Food Science 7: 191-197.

Setiaji, B. dan Prayugo, S. (2006). Membuat VCO Berkualitas Tinggi. Penebar Swadaya Jakarta.

Sorgentini, D.A. dan Wagner, J.R. (2001). Comparative study of foaming properties of whey and isolate soybean proteins. Food Research International 35: 721-729.

Subagio, A. (2006). Characterization of hyacinth bean Lablab purpureus (L.) Sweet seeds from Indonesia and their protein isolate. Food Chemistry 95: 65-70.
Suzana, N. (2006). Sifat Kimia dan Fisika pada Biskuit dari Blondo Hasil Samping Pengolahan Minyak Kelapa Murni. Skripsi. Jurusan Kimia Fakultas Matematika dan Ilmu Pengetahuan Alam. Universitas Gadjah Mada, Yogyakarta.

Sze-Tao, K.W.C. dan Sathe, S.K. (2000). Functional properties and in vitro digestibility of almond (Prunus dulcis L.) protein isolate. Food Chemistry 69: 153-160.

Tsaliki, E., Kechagia, U. dan Doxastakis, G. (2003). Evaluation of the foaming properties of cottonseed protein isolates. Food Hydrocolloids 16: 645-652.

Winarti, S., Jariyah, dan Purnomo, Y. (2007). Proses pembuatan VCO (virgin coconut oil) secara enzimatis menggunakan papain kasar. Jurnal Teknologi Pertanian 8(2): 136-141.

Zayas, J.F. (1997). Functionality of Protein in Food. SpringerVerlag, Berlin Heidelberg. 